\title{
Clinical Course of Histologically Proven Multifocal Micronodular Pneumocyte Hyperplasia in Tuberous Sclerosis Complex: A Case Series and Comparison with Lymphangiomyomatosis
}

\author{
Satoshi Konno ${ }^{a}$ Masahiko Shigemura $^{a}$ Takahiro Ogi $^{\mathrm{a}, \mathrm{b}}$ Kaoruko Shimizu ${ }^{\mathrm{a}}$ \\ Masaru Suzuki $^{a}$ Kichizo Kaga ${ }^{c}$ Yasuhiro Hida ${ }^{c}$ Yoshihiro Matsuno ${ }^{d}$ \\ Masaharu Nishimura ${ }^{a}$

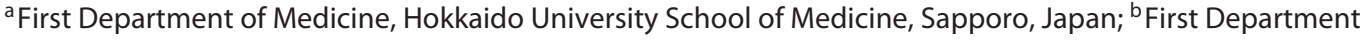 \\ of Medicine, Obihiro Kosei General Hospital, Obihiro, Japan; ' Cardiovascular and Thoracic Surgery, Hokkaido \\ University School of Medicine, Sapporo, Japan; ${ }^{d}$ Department of Surgical Pathology, Hokkaido University Hospital, \\ Sapporo, Japan
}

\section{Keywords}

Multifocal micronodular pneumocyte hyperplasia •

Clinical course · Lymphangiomyomatosis · High-resolution computed tomography - DLCO - Surfactant protein-A .

Surfactant protein-D $\cdot \mathrm{KL}-6$

\begin{abstract}
Background: Multifocal micronodular pneumocyte hyperplasia (MMPH) is a rare pulmonary manifestation of tuberous sclerosis complex (TSC). Because of its rarity, no previous study has described the detailed clinical course of this disease. Objectives: This study aimed to clarify the longitudinal clinical characteristics of subjects with MMPH. Methods: Nine patients with MMPH diagnosed at Hokkaido University Hospital were retrospectively analyzed. Changes in computed tomography findings and pulmonary function were compared during the follow-up period. Serum levels of KL-6, surfactant protein (SP)-A, and SP-D were measured to clarify
\end{abstract}

their potentials as blood biomarkers of the disease. Fourteen cases of lymphangiomyomatosis (LAM) were also included to compare their clinical characteristics with those of subjects with MMPH. Results: Of the 9 patients, 7 were female and 2 were male. The median age at diagnosis was 43 years (range, 19-56), and all cases were diagnosed following incidental abnormal radiographic findings. During the followup, 1 patient died of lung cancer, but others were radiographically stable and had stable pulmonary function. Serum levels of SP-A in 5 patients (mean, $146.4 \mathrm{ng} / \mathrm{mL}$ ) and SP-D in 6 patients (mean, $337.3 \mathrm{ng} / \mathrm{mL}$ ) were elevated in subjects with $\mathrm{MMPH}$, whereas $\mathrm{KL}-6$ levels were within the reference range (mean, $230 \mathrm{U} / \mathrm{mL}$ ) in all patients. Levels of SP-A and SP-D were significantly higher in subjects with MMPH than those with LAM $(p<0.05)$. Conclusions: Radiographic findings and pulmonary function were stable in all cases of MMPH. Serum SP-A and SP-D, but not KL-6, may be useful markers for suspicion of the presence of MMPH in patients with TSC.

\section{KARGER}

(c) 2018 S. Karger AG, Basel

E-Mail karger@karger.com

www.karger.com/res
Satoshi Konno

First Department of Medicine, Hokkaido University School of Medicine Kita-15 Nishi-7 Kita-Ku, Sapporo, Hokkaido 060-8638 (Japan)

E-Mail satkonno@med.hokudai.ac.jp 


\section{Introduction}

Multifocal micronodular pneumocyte hyperplasia $(\mathrm{MMPH})$ is a rare pulmonary disease, which usually manifests as tuberous sclerosis complex (TSC). It is characterized by multiple, small ground-glass nodular shadows on chest computed tomography (CT). Histological examination typically reveals multicentric, well-demarcated, nodular type II pneumocystic growth $[1,2]$. In contrast with lymphangioleiomyomatosis (LAM), which is a more common lung manifestation in patients with TSC [3], MMPH is less progressive $[4,5]$. However, because of its rarity, no previous study has described the detailed clinical course of the disease, such as changes in radiographic findings and pulmonary function. In addition, there is no report of blood biomarkers associated with this disease.

In this study, we retrospectively evaluated the clinical features of 9 patients consecutively diagnosed with MMPH via pathological findings. We focused on radiological findings, pulmonary function testing, and serum biomarkers. Examination results were compared between each patient's initial visit and most recent follow-up visit. We included 14 patients with LAM as controls, particularly for serum biomarker comparisons, which indicated hyperplasia of type II pneumocytes such as Krebs von den Lungen-6 (KL-6), surfactant protein (SP)-A, and SP-D, in patients with MMPH.

\section{Materials and Methods}

This study was approved by the Research Review Boards of Hokkaido University (15-041) and Hokkaido University Hospital (017-017). Written informed consent was obtained directly from doctors. Details pertaining to study materials and methods are described in the online supplement to this paper (for all online suppl. material, see www.karger.com/doi/10.1159/000486101).

\section{Patients with MMPH}

Nine patients with MMPH participated in this retrospective cohort study. All were consecutively diagnosed via pathology and exhibited clinical features suspicious for TSC during their examinations at the First Department of Medicine, Hokkaido University Hospital, between 2000 and 2013.

\section{Pulmonary Function Test}

Details of the pulmonary function tests are described in the online supplement and in our previous report $[6,7]$.

\section{Measurement of Serum Biomarkers}

We measured KL-6 concentrations in serum using an electrochemiluminescence immunoassay (PICOLUMI KL-6 kit; Sanko Junyaku, Tokyo, Japan). SP-A concentrations were measured us- ing an enzyme immunoassay (BML, Inc., Sapporo, Japan). SP-D concentrations were measured using a cloned enzyme donor immunoassay (BML, Inc.). Serum cutoff values were set at $500 \mathrm{U} / \mathrm{mL}$ for KL-6, $43.8 \mathrm{ng} / \mathrm{mL}$ for SP-A, and $110 \mathrm{ng} / \mathrm{mL}$ for SP-D based on previous reports [8-10].

\section{Follow-Up Data}

One patient (case 4) developed lung cancer 1 year after referral to our hospital [11]. Regarding the other 8 patients, follow-up data were obtained for durations of 4-13 years. We retrospectively compared high-resolution CT (HRCT) findings, pulmonary function test results, and serum biomarkers between the initial diagnosis and follow-ups. The HRCT findings were reviewed independently by a radiologist and a respiratory physician (S.K.).

\section{Patients with LAM}

As a reference for MMPH, particularly for comparing serum markers, we included 14 patients with pathologically diagnosed LAM who had been followed up consecutively at our hospital since 2006. Twelve patients were referred to our hospital after being diagnosed at a previous hospital. No LAM case presented pathological or radiological findings related to $\mathrm{MMPH}$.

\section{Immunohistochemical Staining}

The specimens were fixed in 10\% formaldehyde and embedded in paraffin. The sections were incubated with protein blocker (Dako; Glostrup, Denmark) for $30 \mathrm{~min}$ and incubated at $4{ }^{\circ} \mathrm{C}$ overnight with rabbit anti-human IgG antibody (Dako) and mouse anti-human primary antibodies as follows: HMB-45 (Dako) and KL-6 (kindly provided by Esai Co., Ltd., Tokyo, Japan; lot D851308R).

\section{Genotyping of MUC1 Gene Polymorphism}

The MUC1 SNP (exon 2; rs4072037) was genotyped using the TaqMan system (assay ID: C_27532642_10; Applied Biosystems, Foster City, CA, USA), as described previously [12, 13].

\section{Statistical Analysis}

Differences of serum SP-A and SP-D levels between subjects with MMPH and LAM were analyzed using the Mann-Whitney U test. Statistical analysis was performed using a statistical software package (SYSTAT for Windows, version 11; Systat, San Jose, CA, USA). Significance was defined as $p<0.05$.

\section{Results}

\section{Characteristics of the 9 Cases of $M M P H$}

The clinical characteristics of the 9 patients with MMPH at initial diagnosis are shown in Table 1. Two patients were male, and the median age at diagnosis was 43 years (range, 19-56). Six patients exhibited abnormalities during routine chest radiography, 2 exhibited abnormalities of HRCT by health checkup, and 1 was an incidental cough following a chest CT scan. Five patients exhibited definite criteria for TSC and 4 for possible TSC [14] (see online suppl. data). No patients had respiratory symp- 
Table 1. Clinical characteristics of 9 cases of $\mathrm{MMPH}$

\begin{tabular}{|c|c|c|c|c|c|c|c|c|c|}
\hline Case & $\begin{array}{l}\text { Age at } \\
\text { diagnosis, } \\
\text { years }\end{array}$ & Sex & $\begin{array}{l}\text { Reason for visiting } \\
\text { the hospital }\end{array}$ & $\mathrm{TSC}^{\mathrm{a}}$ & LAM & $\begin{array}{l}\text { Other manifestations } \\
\text { related with TSC }\end{array}$ & $\begin{array}{l}\text { Diagnostic } \\
\text { methods }\end{array}$ & $\begin{array}{l}\text { Follow-up } \\
\text { period }^{\mathrm{b}} \\
\text { years }\end{array}$ & Outcome \\
\hline 2 & 23 & $\mathrm{~F}$ & pneumothorax & definite & + & renal angiomyolipoma & VATS & 10 & survival \\
\hline 5 & 31 & $\mathrm{~F}$ & $\operatorname{cough}^{c}$ & possible & - & $\begin{array}{l}\text { hypomelanotic macules, } \\
\text { cortical tubers }\end{array}$ & VATS & 9 & survival \\
\hline 6 & 34 & $\mathrm{M}$ & abnormal chest X-ray & definite & - & $\begin{array}{l}\text { angiofibroma, Koenen's } \\
\text { tumor }\end{array}$ & VATS & 7 & survival \\
\hline 9 & 32 & $\mathrm{M}$ & $\begin{array}{l}\text { health checkup } \\
\text { (HRCT) }\end{array}$ & definite & - & $\begin{array}{l}\text { hypomelanotic macules, } \\
\text { subependymal nodules, } \\
\text { cortical dysplasia, } \\
\text { impaired intelligence }\end{array}$ & TBLB & 4 & survival \\
\hline
\end{tabular}

MMPH, Multifocal micronodular pneumocyte hyperplasia; TSC, tuberous sclerosis complex; LAM, lymphangiomyomatosis; VATS, video-assisted thoracic surgery; TBLB, transbronchial lung biopsy; HRCT, high-resolution computed tomography. ${ }^{\text {a }}$ Defined in 2012 [14]. ${ }^{b}$ Until final examinations for the pulmonary function tests. ${ }^{c}$ Not related with MMPH. ${ }^{d}$ Died of lung cancer [11].

Fig. 1. HRCT findings of 3 representative cases. a Case 5: several nodular shadows measuring 1-7 mm in size in the bilateral upper and middle lung fields (pink arrows). b Case 4: bilateral, diffuse, nodular ground-glass opacities extending from the upper to the lower lobes. c Case 2: a case of multifocal micronodular pneumocyte hyperplasia with lymphangiomyomatosis co-occurrence (pink arrows show small nodules).

toms such as a cough, sputum, or dyspnea at the time of the pathological diagnosis.

\section{Chest Radiographic Findings}

HRCT of the chest revealed bilateral nodular groundglass opacities (GGOs) with a wide distribution range.
Figure 2 shows HRCT findings that are representative of the 9 cases. Figure 1a represents the mildest case (case 6), Figure $1 \mathrm{~b}$ the most diffuse case (case 4 ), and Figure $1 \mathrm{c}$ is a case with co-occurring multiple cystic lesions and pneumothorax, which were pathologically confirmed as LAM (case 2). 
Table 2. Comparisons of pulmonary function and serum biomarkers between diagnosis and follow-up

\begin{tabular}{|c|c|c|c|c|c|c|c|c|c|c|c|c|c|c|}
\hline \multirow[t]{2}{*}{ Case } & \multicolumn{2}{|l|}{$\% \mathrm{VC}$} & \multicolumn{2}{|l|}{$\% \mathrm{FEV}_{1}$} & \multicolumn{2}{|c|}{ DLCO \% predicted ${ }^{\mathrm{a}}$} & \multicolumn{2}{|c|}{ SP-D, ng/mL } & \multicolumn{2}{|c|}{ SP-A, ng/mL } & \multicolumn{2}{|c|}{$\mathrm{KL}-6, \mathrm{U} / \mathrm{mL}$} & \multirow{2}{*}{$\begin{array}{l}\text { MUC1 } \\
\text { genotype } \\
\text { rs } 4072037\end{array}$} & \multirow{2}{*}{$\begin{array}{l}\text { Follow-up } \\
\text { period }^{\text {b }} \\
\text { years }\end{array}$} \\
\hline & diagnosis & $\begin{array}{l}\text { follow- } \\
\text { up }\end{array}$ & diagnosis & $\begin{array}{l}\text { follow- } \\
\text { up }\end{array}$ & diagnosis & $\begin{array}{l}\text { follow- } \\
\text { up }\end{array}$ & diagnosis & $\begin{array}{l}\text { follow- } \\
\text { up }\end{array}$ & diagnosis & $\begin{array}{l}\text { follow- } \\
\text { up }\end{array}$ & diagnosis & $\begin{array}{l}\text { follow- } \\
\text { up }\end{array}$ & & \\
\hline 1 & 97.7 & 110.6 & 90.1 & 47.7 & 67.5 & 13.0 & 199.1 & 200.2 & 52.9 & 55.3 & 205 & 238 & AA & 13 \\
\hline 2 & 92.1 & 79.2 & 101.2 & 86.0 & 66.8 & 28.5 & 170.5 & 71.7 & 31.2 & 23.9 & 250 & 217 & AA & 10 \\
\hline 3 & 99.2 & 101.0 & 104.4 & 101.0 & 74.5 & 68.5 & 225.0 & 188.1 & 132.0 & 152.0 & 203 & 284 & $\mathrm{AA}$ & 7 \\
\hline 4 & 110.3 & 104.8 & 109.4 & 103.2 & 84.0 & 92.8 & 859.0 & 782.4 & 252.0 & 347.3 & 244 & 309 & N/A & 1 \\
\hline 5 & 79.1 & 81.9 & 82.3 & 86.5 & 64.3 & 84.9 & 149.0 & 91.6 & 77.6 & 74.8 & 244 & 203 & $\mathrm{AG}$ & 9 \\
\hline 6 & 118.1 & 120.0 & 97.8 & 95.1 & 93.5 & 95.3 & 116.3 & 170.7 & 24.3 & 25.2 & 227 & 225 & $\mathrm{AG}$ & 7 \\
\hline 7 & 113.4 & 117.5 & 114.9 & 105.3 & 97.5 & 128.5 & 75.4 & 60.5 & 124.0 & 68.3 & 232 & 176 & $\mathrm{AA}$ & 7 \\
\hline 8 & 83.0 & 96.0 & 100.2 & 94.9 & 87.6 & 89.6 & 209.0 & 494.2 & 93.3 & 115.8 & 288 & 289 & $\mathrm{AG}$ & 5 \\
\hline 9 & 72.2 & 73.8 & 66.5 & 67.6 & 84.1 & 80.5 & 134.2 & 211.9 & 30.0 & 47.2 & 188 & 179 & $\mathrm{AG}$ & 4 \\
\hline
\end{tabular}

Normal range: SP-D (0-109.9 ng/mL), SP-A (0-43.7 ng/mL), KL-6 (0-400 U/mL). Italics: values above the reference range for biomarkers. VC, vital capacity; $\mathrm{FEV}_{1}$, forced expiratory volume in $1 \mathrm{~s}$; DLCO, diffusing capacity for carbon monoxide of the lung. ${ }^{a}$ Hemoglobin-adjusted value. ${ }^{\mathrm{b}}$ Until final examinations for the pulmonary function tests.

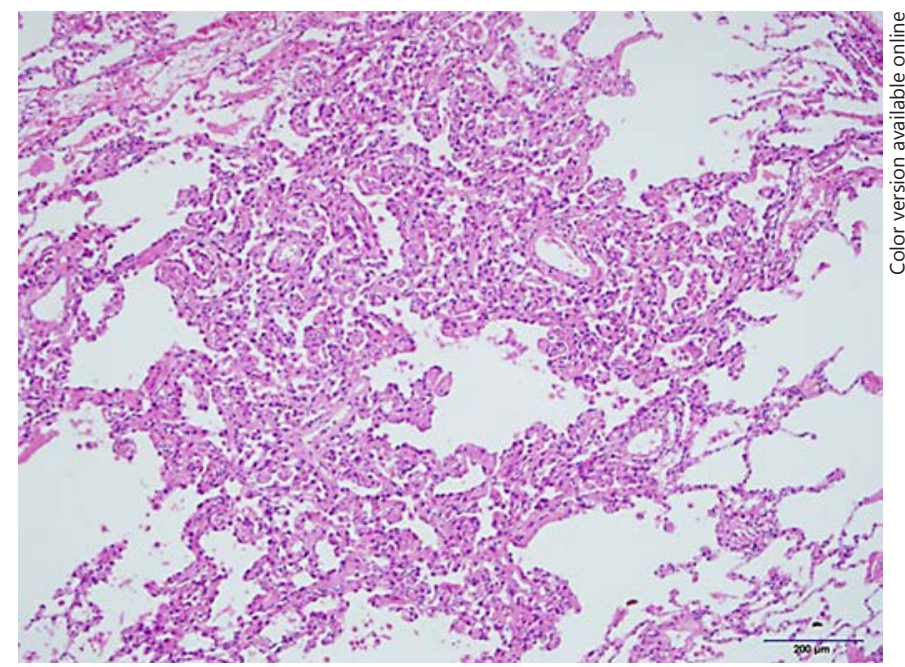

Fig. 2. Histopathological findings (case 4). Enlarged type II pneumocytes that have proliferated, with fibrous thickening of the alveolar septa. Lymphocytes are seen to have infiltrated the thickened alveolar septa. HE stain. $\times 100$.

\section{Pathological Findings}

Thoracoscopic lung biopsies (video-assisted thoracoscopic surgery) were performed for 7 cases, and transbronchial lung biopsies for 2 cases. A representative histological finding is shown in Figure 2 (case 4). Type II pneumocytes are enlarged and vary in shape from flattened to cuboidal or round, proliferating in a papillary or tubercular pattern. These pneumocytes did not demonstrate mitotic figures or intracytoplasmic inclusion bodies. Fibrous thickening and an increase in elastic fibers in the alveolar septa were also observed. Immunoreactive cells for HMB45, suggestive of LAM cells, were not found except in cases 1 and 2.

\section{Pulmonary Function Tests}

We calculated the mean value of each parameter, excluding cases 1 and 2 as these had co-occurrence of LAM. The mean ( \pm standard deviation, $\mathrm{SD}) \% \mathrm{VC}, \% \mathrm{FEV}_{1}$, and $\mathrm{FEV}_{1} / \mathrm{FVC}$ values were 96.5 (17.0), 96.5 (15.5), and 86.4 (6.9), respectively. The mean $( \pm$ SD) \%DLCO was 83.6 (10.4) (Table 2).

\section{Serum Levels of SP-D, SP-A, and KL-6}

Eight patients showed high serum SP-D levels $(>110$ $\mathrm{ng} / \mathrm{mL}$ ), and 1 patient (case 7 ) exhibited high SP-A ( $>43.8$ $\mathrm{ng} / \mathrm{mL}$ ). In contrast, the serum KL-6 levels of all patients were within the normal range (reference $<500 \mathrm{U} / \mathrm{mL}$ ) (Table 2).

\section{Follow-Up Data in Patients with MMPH}

Case 4 developed giant cell carcinoma and adenocarcinoma of the lung 1 year after the diagnosis of $\mathrm{MMPH}$ and died 1 year after the lung cancer diagnosis [14]. Thus, only 1 year of follow-up data were obtained for this patient. Other patients provided at least 4 years of follow-up data (range, 4-13 years). We retrospectively compared the follow-up radiographic findings, pulmonary function tests, and serum markers with those at the initial diagnosis. Regarding HRCT findings, all patients remained unchanged at follow-up (data not shown). Findings suggestive of the presence of LAM did not emerge during the follow-up period. Cases 1 and 2, who had co-occurrences 
Table 3. Clinical characteristics of 14 cases of LAM at the initial visit to our hospital

\begin{tabular}{|c|c|c|c|c|c|c|c|c|c|c|}
\hline Case & $\begin{array}{l}\text { Age at } \\
\text { diagnosis, } \\
\text { years }\end{array}$ & $\begin{array}{l}\text { Age at initial } \\
\text { visit, years }\end{array}$ & $\mathrm{TSC}^{\mathrm{a}}$ & $\begin{array}{l}\text { VC, L } \\
(\% \mathrm{VC})\end{array}$ & $\begin{array}{l}\mathrm{FEV}_{1}, \mathrm{~L} \\
\left(\% \mathrm{FEV}_{1}\right)\end{array}$ & $\begin{array}{l}\mathrm{FEV}_{1} / \\
\mathrm{FVC}, \\
\%\end{array}$ & $\begin{array}{l}\text { DLCO, } \\
\% \text { pre- } \\
\text { dicted }^{b}\end{array}$ & $\begin{array}{l}\text { SP-D, } \\
\mathrm{ng} / \mathrm{mL}\end{array}$ & $\begin{array}{l}\mathrm{SP}-\mathrm{A}, \\
\mathrm{ng} / \mathrm{mL}\end{array}$ & $\begin{array}{l}\text { KL-6, } \\
\mathrm{U} / \mathrm{mL}\end{array}$ \\
\hline 2 & 32 & 34 & - & $2.92(86.0)$ & $1.77(62.9)$ & 62.5 & 39.9 & 64.0 & 42.0 & 148 \\
\hline 3 & 31 & 40 & - & $1.40(40.9)$ & $1.30(46.9)$ & 99.1 & 22.7 & 61.6 & 72.2 & 299 \\
\hline 4 & 32 & 39 & - & $1.61(49.6)$ & $0.44(16.5)$ & 27.0 & 11.2 & 51.7 & 36.2 & 445 \\
\hline 7 & 52 & 52 & - & $3.47(111.5)$ & $2.26(92.5)$ & 66.2 & 88.0 & $<17.3$ & 25.5 & 164 \\
\hline 8 & 39 & 39 & - & $3.17(97.3)$ & $1.41(52.8)$ & 43.3 & 36.0 & 72.6 & 45.3 & 267 \\
\hline 9 & 26 & 27 & - & $3.51(100.4)$ & $2.80(94.9)$ & 79.3 & 72.9 & 163.9 & 27.7 & 203 \\
\hline 10 & 49 & 50 & - & $2.31(83.3)$ & $2.09(93.7)$ & 92.7 & 65.6 & 41.8 & 21.4 & 378 \\
\hline 11 & 30 & 30 & - & $1.99(54.8)$ & $1.94(61.4)$ & 98.1 & 49.2 & 39.6 & 33.9 & 337 \\
\hline
\end{tabular}

All subjects were female. Levels were measured at the initial visit to our hospital. Normal range: SP-D (0-109.9 ng/mL), SP-A (0-43.7 ng/mL), KL-6 (0-400 U/mL). Italics: values above the reference range. LAM, lymphangiomyomatosis; TSC, tuberous sclerosis complex; VC, vital capacity; $\mathrm{FEV}_{1}$, forced expiratory volume in $1 \mathrm{~s}$; DLCO, diffusing capacity for carbon monoxide of the lung; SP, surfactant protein. ${ }^{a}$ Definite diagnosis defined in 2012 [14]. ${ }^{\mathrm{b}}$ Hemoglobin-adjusted value.

Fig. 3. Comparisons of serum surfactant protein (SP)-A and SP-D between subjects with multifocal micronodular pneumocyte hyperplasia (MMPH) and lymphangiomyomatosis (LAM). Serum SP-A and SP-D levels at the initial visit to our hospital were significantly higher in subjects with $\mathrm{MMPH}$ than those with LAM. Mann-Whitney U test.

of LAM, showed deterioration in \%VC, $\% \mathrm{FEV}_{1}, \mathrm{FEV}_{1} /$ $\mathrm{FVC}$, and \%DLCO during the follow-up period (Table 2). Among the other 7 subjects, neither \%VC, \%FEV1, nor $\%$ DLCO changed during the follow-up period. Serum KL-6 remained in the normal ranges and serum SP-D (SP-A in case 7) remained high after follow-up (Table 2).

\section{Characteristics of the 14 Cases of LAM}

The clinical characteristics of the 14 patients with LAM are shown in Table 3. All patients were female. The median age at diagnosis was 42 years (range, 26-55) and the median age at referral to our hospital was 42 years (range, 27-55). Three cases showed definite criteria for 
TSC [14] (see online suppl. data). The mean ( \pm SD) $\% \mathrm{VC}, \% \mathrm{FEV}_{1}$, and $\mathrm{FEV}_{1} / \mathrm{FVC}$ values were 89.2 (24.0), 79.6 (29.6), and 73.6 (19.3), respectively. The mean $( \pm$ SD) \%DLCO was 61.9 (26.0). Three patients showed high levels of SP-D (>110 ng/mL) or SP-A $(>43.8 \mathrm{ng} /$ $\mathrm{mL}$ ) (cases 8,9 , and 12), whereas KL-6 levels were within the normal range (reference $<500 \mathrm{U} / \mathrm{mL}$ ) for all patients.

\section{Comparisons of Serum SP-A and SP-D Levels in \\ Subjects with MMPH and LAM}

As shown in Figure 3, serum SP-A and SP-D levels at the initial visit to our hospital were significantly higher in subjects with MMPH than those with LAM $(p<0.05)$ : median (range) SP-A: 77.6 (24.3-225.0) for MMPH and 33.8 (18.0-72.2) for LAM; SP-D: 170.5 (75.4-859.0) for MMPH and 48.4 (17.3-163.9) for LAM.

\section{Discussion}

Because of the rarity of MMPH, its clinical course remains unclear. Previous reports described only 2 patients who may have died from respiratory failure, possibly due to MMPH deterioration $[15,16]$. Generally, the prognoses in most previously reported cases of MMPH seemed fair $[4,5]$. In our case series, all 9 patients, even the 19-year-old patient, had not deteriorated at follow-up when clinical findings, radiographic findings, pulmonary function test results, and serum biomarkers were assessed. This caused us to question when the patients' diseases developed. A recent report from Japan describes a patient diagnosed at the age of 13 years, although this case was not pathologically confirmed [17]. Unfortunately, radiographic findings were not available for all cases before the diagnosis. Thus, we cannot know when the MMPH lesions emerged. Given that not all cases showed deterioration for at least several years after diagnosis, we speculate that MMPH develops at a young age and does not deteriorate until after adolescence.

We previously demonstrated that serum KL-6 levels were determined by the MUC1 genotype (rs4072037) and its alveolar-blood efflux behavior according to the molecular size. The A allele was linked with a small KL-6/ MUC1 molecular size and low serum KL-6 levels. The G allele was linked with a large molecular size and high serum KL-6 levels $[12,13]$. MMPH is characterized by hyperplasia of type II pneumocytes, which we also confirmed by immunohistochemical staining (see online suppl. Fig. E1). However, in all 9 patients, serum KL-6 was within the normal range, even in patients with the AG genotype (Table 3 ), which is liked with a large molecular size of KL-6/MUC1. Serum KL-6 was also within the normal range, even in the case showing the most diffuse distribution of GGOs on HRCT (case 4). These findings suggest that serum KL-6 is not solely determined by high lung production; it requires other conditions, such as structural alveolar destruction and/or extracellular domain cleavage by proteinase for the soluble form to increase [18].

In contrast to KL-6, all patients with MMPH showed increased serum levels of either SP-A or SP-D, which are also biomarkers associated with type II alveolar cell proliferation $[19,20]$. While KL-6 is a structural component of the cell membrane with an extracellular domain that binds to the cell surface, SP-A and SP-D are secretory molecules. This could be a plausible explanation for the behavioral differences between KL-6 and SP-A or SP-D [18]. The leakage behavior from the alveoli into the blood circulation likely differs between KL-6 and SP-A or SP-D in patients with MMPH. Thus, MMPH could be a good human model and potentially explain the lung-specific biomarker behavior from the alveoli into the blood circulation. Furthermore, only 2 of 14 patients with LAM showed increases in SP-A and SP-D. This indicates that the increases in SP-A and SP-D could be clinically useful in predicting the presence of MMPH when we diagnose patients exhibiting TSC and/or LAM.

A recent study by Tanaka et al. [17] suggested that DLCO indicates the presence of LAM but not MMPH in patients with TSC. Among our patients, the 2 who had both MMPH and LAM showed significant decreases in $\%$ DLCO during the follow-up (Table 2). However, in patients with MMPH, the levels of \%DLCO and degrees of GGO lung field spread did not appear to be correlated. In fact, 1 patient (case 4), who showed the most diffuse GGO distribution in a wide lung field, had a normal \%DLCO. Thus, in line with the recent report from Tanaka et al. [17], the \%DLCO may not significantly decrease in patients with MMPH, even in severe cases, according to chest radiographic findings.

There were some limitations to this study. Because of the extreme rarity of this disease, the total number of patients was small despite our hospital being the lead referral hospital in our province. In addition, the follow-up period was short for some patients (case 3, 1 year; case 7, 4 years); thus, these patients may have deteriorated later on. Longer-term evaluations and follow-ups in a larger patient cohort are needed to clarify the longitudinal aspects of the clinical courses of these patients.
$6 \quad$ Respiration DOI: $10.1159 / 000486101$
Konno/Shigemura/Ogi/Shimizu/Suzuki/ Kaga/Hida/Matsuno/Nishimura 
In conclusion, we described the clinical courses of 9 patients with MMPH who were pathologically diagnosed at our university hospital. No cases exhibited pulmonary function deterioration on HRCT during the follow-up period. Serum SP-A and SP-D, but not KL-6, may be useful markers for detecting disease activity in patients with MMPH. Further reports examining this rare disease are warranted to identify the exact age of onset and the clinical course.

\section{Financial Disclosure and Conflicts of Interest}

The authors have no conflicts of interest to declare. No funding was received for this study.

\section{Author Contributions}

S. Konno and M. Shigemura were involved in the study concept and design, statistical analysis, interpretation of data, and drafting the manuscript. T. Ogi carried out the statistical analysis and interpretation of data. K. Shimizu and M. Suzuki were involved in interpretation of data and drafting the manuscript. K. Kaga and Y. Hida performed the surgical biopsies. Y. Matsuno carried out the pathological examination. M. Nishimura was involved in interpretation of data and drafting the manuscript.

\section{References}

1 Popper HH, Juettner-Smolle FM, Pongratz MG: Micronodular hyperplasia of type II pneumocytes - a new lung lesion associated with tuberous sclerosis. Histopathology 1991; $18: 347-354$

-2 Guinee D, Singh R, Azumi N, Singh G, Przygodzki RM, Travis W, Koss M: Multifocal micronodular pneumocyte hyperplasia: a distinctive pulmonary manifestation of tuberous sclerosis. Mod Pathol 1995;8:902-906.

3 Lama A, Ferreiro L, Golpe A, Gude F, Alvarez-Dobano JM, Gonzalez-Barcala FJ, Toubes ME. Jose ES, Rodriguez-Nunez N, Valdes L: Characteristics of patients with lymphangioleiomyomatosis and pleural effusion: a systematic review. Respiration 2016;91:256-264.

-4 Kobayashi Y, Sugiu T, Mouri K, Irei T, Nakata M, Oka M: Clinicopathological analysis of multifocal micronodular pneumocyte hyperplasia associated with tuberous sclerosis in Japan. Respirology 2008;13:1076-1081.

-5 sMuir TE, Leslie KO, Popper H, Kitaichi M, Gagné E, Emelin JK, Vinters HV, Colby TV: Micronodular pneumocyte hyperplasia. Am J Surg Pathol 1998;22:465-472.

-6 Nishimura M, Makita H, Nagai K, Konno S, Nasuhara Y, Hasegawa M, Shimizu K, Betsuyaku T, Ito YM, Fuke S, Igarashi T, Akiyama Y, Ogura S: Annual change in pulmonary function and clinical phenotype in chronic obstructive pulmonary disease. Am J Respir Crit Care Med 2012;185:44-52.

-7 Kimura H, Konno S, Nakamaru Y, Makita H, Taniguchi N, Shimizu K, Suzuki M, Ono J, Ohta S, Izuhara K, Nishimura M; Hokkaidobased Investigative Cohort Analysis for Refractory Asthma Investigators: Sinus computed tomographic findings in adult smokers and nonsmokers with asthma. Analysis of clinical indices and biomarkers. Ann Am Thorac Soc 2017; 14:332-341.

8 Kitamura S, Hiwada K, Kobayashi J, Kohno N, Kawai T, Satou A, Kasukawa R, Kawakami Y, Andou M, Nakada G, Inoue H, Itou K, Matsushima T, Ogura T, Arakawa M, Yamakido M: Use of the ED046 kit to analyze serum KL-6 in patients with pneumonitis (in Japanese). Nihon Kyobu Shikkan Gakkai Zasshi 1996;34:639-645.

-9 Honda Y, Kuroki Y, Shijubo N, Fujishima T, Takahashi H, Hosoda K, Akino T, Abe S: Aberrant appearance of lung surfactant $\mathrm{A}$ in sera of patients with idiopathic pulmonary fibrosis and its clinical significance. Respiration 1995; 62:64-69.

10 Nagae H, Takahashi H, Kuroki Y, Honda Y, Nagata A, Ogasawara Y, Abe S, Akino T: Enzyme-linked immunosorbent assay using $\mathrm{F}\left(\mathrm{ab}^{\prime}\right)_{2}$ fragment for the detection of human pulmonary surfactant D in sera. Clin Chim Acta 1997;266:157-171.

11 Maki K, Konno S, Oizumi S, Sakakibara-Konishi J, Nagai K, Taniguchi T, Ogura I, Kaga K, Matsuno Y, Nishimura M: Co-occurrence of giant cell carcinoma and adenocarcinoma of the lung accompanied by multifocal micronodular pneumocyte hyperplasia associated with tuberous sclerosis. Int Cancer Conf J 2013;2:215-219.

12 Shigemura M, Nasuhara Y, Konno S, Shimizu C, Matsuno K, Yamguchi E, Nishimura M: Effects of molecular structural variants on serum Krebs von den Lungen-6 levels in sarcoidosis. J Transl Med 2012;10:111.

13 Shigemura M, Konno S, Nasuhara Y, Shijubo N, Shimizu C, Nishimura M: Serum KL-6 concentrations are associated with molecular sizes and efflux behavior of KL-6/MUC1 in healthy subjects. Clin Chim Acta 2013;424: 148-152.

14 Northrup H, Kruege DA: Tuberous sclerosis complex diagnostic criteria update: recommendations of the 2012 international tuberous sclerosis complex consensus conference. Pediatr Neurol 2013;49:243-254.

15 Cancellieri A, Poletti V, Corrin B: Respiratory failure due to micronodular type II pneumocyte hyperplasia. Histopathology 2002;41: 263-265.

16 Hosokawa Y, Tsuchihashi Y, Ochiai K, Hino R, Kuga M, Ashihara T: An autopsy case of tuberous sclerosis with multiple hamartomatosis (in Japanese). Rinsho Byori 1990;8:389-396.

17 Tanaka M, Hirata H, Wataya-Kaneda M, Yoshida M, Katayama I: Lymphangioleiomyomatosis and multifocal micronodular pneumocyte hyperplasia in Japanese patients with tuberous sclerosis complex. Respir Investig 2016;54:8-13.

18 Ishikawa N, Hattori N, Yokoyama A, Kohno $\mathrm{N}$ : Utility of KL-6/MUC1 in the clinical management of interstitial lung diseases. Respir Investig 2012;50:3-13.

19 Takahashi H, Fujishima T, Koba H, Murakami S, Kurokawa K, Shibuya Y, Shiratori M, Kuroki Y, Abe S: Serum surfactant proteins A and $\mathrm{D}$ as prognostic factors in idiopathic pulmonary fibrosis and their relationship to disease extent. Am J Respir Crit Care Med 2000; 162:1109-1114.

20 Ohnishi H, Yokoyama A, Kondo K, Hamada H, Abe M, Nishimura K, Hiwada K, Kohno N: Comparative study of KL-6, surfactant protein-A, surfactant protein-D, and monocyte chemoattractant protein- 1 as serum markers for interstitial lung diseases. Am J Respir Crit Care Med 2000;165:378-381. 